DOI https://doi.org/10.30525/978-9934-588-90-7-59

\title{
ОСОБЛИВОСТІ ЛІНГВАЛЬНОЇ ПРИРОДИ ЕВФЕМІЗМІВ В АНГЛОМОВНОМУ ДИСКУРСІ
}

\author{
Колядич Ю. В. \\ кандидат філологічних наук, \\ доцент кафедри методики навчання іноземних мов \\ Віннииький державний педагогічний університет \\ імені Михайла Коцюбинського \\ м. Вінниця, Україна
}

У сучасному мовному просторі актуальним є дослідження багатої за своєю онтологією проблеми евфемістичної субституції в англійській мові, що доведено виникненням різних підходів до трактування цього явища. Аналіз лексико-семантичних, словотвірних та функціональнопрагматичних особливостей евфемізмів викликає різні погляди та способи їх творення, визначення мотивів вживання мовцями, сфер дистрибуції та їх стильової належності.

Теоретико-методологічну основу нашої статті складають наукові праці вітчизняних та зарубіжних дослідників А. Кацева, Н. Босчаєвої, К. Хем, Дж. Лоуренса, В. Ноубла, К. Аллана, К. Баррідж, І. Алєксєєвої, С. Відлак, В. Кравченка, Б. Ларіна, Н. Розанової та ін. Але особливості зв'язку евфемії з іншими соціолінгвальними тенденціями узусу, а саме табу, арго, дисфемією, «політичною коректністю», сленгом тощо залишаються недостатньо дослідженими [3, с. 236; 4, с. 15; 5, с. 51].

Метою статті $\epsilon$ визначення особливостей лінгвальної природи евфемізмів, їх функціонування.

У студіях сучасних учених евфемізми розглядаються як одиниці вторинної номінації 3 відносно позитивною конотацією, що використовуються для заміни прямих найменувань, вживання яких 3 соціально чи психологічно зумовлених причин вважається небажаним. Розширене трактування евфемізмів зумовлено тим, що сучасні евфемізми сфер реклами, політики, медицини тощо необов'язково замінниками грубого чи образливого слова, денотат не в усіх випадках різко негативний, а спектр причин вживання мовцями сучасних евфемізмів дещо різноманітніший, аніж традиційно вважалося раніше [6, с. 134]:

- бажання бути ввічливим (виявлення поваги, прагнення звучати «аристократично», бажання пом'якшити неприємний факт чи уникнути дискримінації тощо): memorial service (funeral); grief therapist (undertaker); 
- намір здійснити прагматичний вплив на адресата (намагання підвищити статус особи чи якість речей, бажання підняти настрій, переконати аудиторію тощо): modern, regular (small); Mexican twostep, Montezuma's revenge;

- намір уникнути будь-якого виду табу: Great leveller, final curtain, call (death); intoxicated, balmy (drunk);

- прагнення завуалювати негативні аспекти дійсності в межах певної професійної, соціальної чи вікової групи: action, operation, program (invasion, attack); legally accurate.

До політичних евфемізмів окремі вчені відносять такі лінгвальні вияви інакомовності, в яких відображаються соціальні погляди носіїв мови, іiі інтенції, вербальні стратегії тощо. Політичне інакомовлення та евфемія справді мають спільні риси. До них можна віднести соціальну детермінованість їх утворення у мові, бінарне протиставлення паралельних найменувань, прагнення до «завуальовування» поняттєвого компоненту в семантиці слів. І. Гальперін, А. Кацев вважають, що термін «політичні евфемізми» охоплює назви понять, які створено з метою перекручування фактів, зокрема, суспільно-політичних [1, с. 5; 2, с. 211; 3, с. 381; 4, с. 17].

Аналіз евфемізмів дає підстави вважати, що табуюванню підлягають не самі поняття, а тільки їх прямі найменування: у своєму денотативному значенні евфемізми повинні повністю збігатися з табуйованими словами.

Складність розмежування політичної інакомовності та політичної евфемії полягає в тому, що паралельні найменування, які наводяться в ролі прикладів евфемізмів у політичній лексиці, семантично позитивні за своєю внутрішньою формою або за новим матеріальним втіленням на відміну від описових політичних виразів, які можуть мати будь-яке емоційно-експресивне забарвлення.

Зважаючи на прагматичні особливості вживання евфемізмів та запропоновані їх трактування виділяємо наступні функції евфемічних субститутів: вуалітивна, конспіративна, дистортивна, кооперуюча, елевативна, превентивна та риторична.

Вуалітивна - виявляє прагнення адресанта приховати аспекти дійсності, про які він не бажає говорити відверто. Вуалітивна функція притаманна усім без винятку евфемізмам; інші функції діють поряд 3 вуалітивною та можуть бути більш або менш виражені. Ця функція евфемізмів простежується в мовленні політиків та громадських діячів.

Конспіративна функиія евфемізмів $є$ помітною у навмисній евфемізації неприйнятних аспектів реальності членами певної соціальної, професійної чи вікової групи задля ускладнення сприймання інформації особами, що до групи не належать: magpie (machinegun), company, customer (CIA, FBI), to hemorrhage (to bleed), D\& C (abortion).

Дистортивна функиія зумовлює спотворене відображення інформації у свідомості адресата й може бути результатом вуалітивної чи конспіративної функції й притаманна політичним, медичним евфемізмам 218 
та евфемізмам реклами. Вона $є$ близькою до вуалітивної, проте приховування таким чином інформації набуває більших масштабів.

Кооперуюча - позначає прагнення комунікантів зберегти мовленнєве співробітництво для вирішення завдань спілкування (притаманна більшості евфемізмів, які вживаються з метою уникнення дискримінації): vertically challenged (short), physically handicapped (crippled), developmentally disabled (retarded), hearing- impaired (deaf), visually challenged (blind), overweight (fat) [6, c. 163].

Елевативна - відображає аспекти реальності у позитивнішому світлі, гіперболізуючи низькі чи середні стандарти. Здебільшого елевативними евфемічними одиницями номінуються професії, організації чи установи, товари та послуги, що за інших обставин не привернули би уваги адресата: large (medium-sized), average-looking (ugly), embalming surgeon (undertaker), access controller (doorman), sanitation engineer (dustman), podiatrist, chiropodist (corncutter) [6, c. 165].

Превентивна функиія евфемізмів передбачає використання евфемічних слів та виразів як альтернативи давніх табу, які ще збережені у свідомості людини (евфемізми на позначення денотатів фізіології людини, смерті, релігійної тематики тощо): Cape of Good Hope, Temple of Venus (female genitals), Father of Lies, old boy, Prince of evil (devil), Creator, Almighty, Savior (God), to sleep (to be dead), to answer the final summons, to pass away (to die) [6, c. 165].

Риторична функція допомагає мовцю певним чином впливати на ціннісні установки адресата, змінювати його ставлення до повідомлюваного, спонукати адресанта до відповідних дій: to reengineer (to fire), de-luxe (expensive), economy (cheap), message (commercial) [6, c. 167].

На думку А. Кацева, евфемістичний потенціал визначається як ступінь здатності евфемізму виконувати свою основну функцію - завуальовувати неприйнятні об'єкти дійсності, викликаючи у свідомості реципієнта позитивніші, порівняно з прямою номінацією, асоціації [4, с. 15].

Отже, евфемічні субститути як вид експресивно забарвленої лексики мають складнішу смислову структуру, ніж нейтральна лексика: евфемізмам властива конотативна семантика, що вбирає в себе всю інформацію і реалізує оцінну та емоційну функції. Емотивно-оцінний компонент разом 3 основою оцінки утворює конотацію евфемізмів, що призводить до переваги прагматичного компонента евфемічних одиниць над сигніфікативним. Евфемічна конотація визначає прагматичне значення евфемізмів - інформацію про суб'єктивно-оцінне, емоційне ставлення до денотата чи самої прямої номінації.

Заявлена тема $є$ актуальною. Вона передбачає вивчення особливостей і взаємодії евфемії та сленгу, розмежуванння евфемії та інакомовлення, компаративного дослідження евфемізмів у британському та американському варіантах англійської мови, стилістичної класифікації евфемізмів з урахуванням евфемізмів-неологізмів. 


\title{
Література:
}

1. Азнаурова Э.С. Функционально-стилистическая и коммуникативно-прагматическая вариативность лексических единиц в системе языка и речи Текст. Проблемы вариативности в германских языках. Москва, 1988. С. 5-6.

2. Антрушина Г. Б., Афанасьева О. В., Морозова Н. Н. Лексикология английского языка. Текст. Москва : Издат. дом «Дрофа», 2001. C. $210-216$.

3. Гальперин И. Р. Очерки по стилистике английского языка. Москва : Изд-во лит-ры на иностр. языке, 1958. 459 с.

4. Кацев А. М. Евфемия в современном английском языке. Опыт социолингвистического описания : автореф. дис. ... канд. филол. наук: 10.02.04. Львов : ЛГПИ имени А. И. Герцена, 1977. 20 с.

5. Розанова Н. Н. Речевые одежды Москвы. Русская речь. 1994. № 3. C. $50-51$.

6. Rawson H. Dictionary of Euphemisms and Other Doubletalk. (Revised Edition). New York : Crown Publishers Inc. 1995. 463 p.

DOI https://doi.org/10.30525/978-9934-588-90-7-60

\section{ОНОМАСТИЧНИЙ ПРОСТІР ХУДОЖНЬОГО ТЕКСТУ \\ ТА ОСОБЛИВОСТІ ПЕРЕКЛАДУ ВЛАСНИХ НАЗВ У ТВОРАХ ЖАНРУ «ФЕНТЕЗІ»}

\author{
Мацюк О. О. \\ кандидат педагогічних наук, \\ доиент кафедри германської філології та перекладознавства \\ Хмельницький національний університет \\ Сергесва О. В. \\ кандидат педагогічних наук, \\ доиент кафедри германської філології та перекладознавства \\ Хмельницький начіональний університет \\ м. Хмельницький, Україна
}

Власні імена та назви утворюють у мові великий пласт лексики, що дозволило виокремити їх вивчення в окрему науку - ономастику, яка вивчає основні закономірності історії, розвитку і функціонування власних назв. Власні назви завжди привертали увагу багатьох лінгвістичних студій, де вивчалися їх словотвірний (О.А. Земська, 